\title{
УДК: (001.89:Василенко):631.3
}

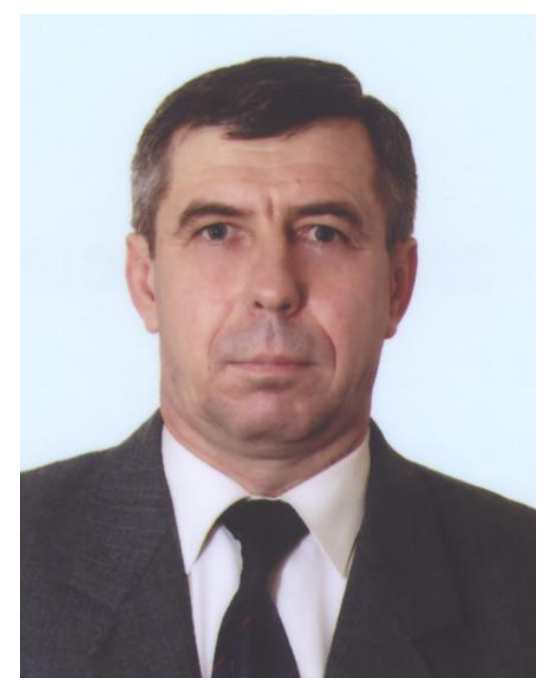

\section{ДЕРКАЧ \\ Олексій Павлович,}

кандидат історичних наук, доцент, доцент кафедри тракторів, автомобілів

та біоенергосистем Національного

університету біоресурсів і

природокористування України

Oleksiy.derkach@gmail.com

(м. Київ)

\section{НАУКОВИЙ ДОРОБОК АКАДЕМІКА П.М. ВАСИЛЕНКА (1900-1999)}

Для українського суспільства, що нині перебуває на стадії оновлення, характерною рисою є зростаюча зачікавленість до історії науки й техніки, зокрема, й до наукової, освітянської та організачійної діяльності видатних вітчизняних вчених, котрі самовіддано прачювали задля розвитку науки та освіти в Україні. За останні роки з'явилися дослідження, що висвітлюють розвиток науки та освіти, зокрема й технічної, через вивчення та осмислення наукової, освітньої та громадської діяльності видатної особистості. Однією з таких особистостей був Петро Мефодійович Василенко - академік Національної академії аграрних наук України, член-кореспондент Національної академії наук України, академік Російської академії сільськогосподарських наук, доктор технічних наук, професор. У галузях землеробської механіки, сільськогосподарського машинобудування, механізаиії, електрифікації та автоматизаиії сільськогосподарського виробництвва України він мав досягнення світового рівня, які прославили вітчизняну науку далеко за межами краӥни. Його по праву називали корифеєм землеробської механіки Украӥни.

Ключові слова: П.М. Василенко, корифей, науковий скарб, вчений, землеробська (сільськогосподарська) механіка, механізація, автоматизачія, сільське господарство.

\section{SCIENTIFIC HERITAGE OF ACADEMICIAN P.M. VASYLENKO}

$$
\text { (1900-1999) }
$$

A characteristic feature of the modern Ukrainian society is the growing interest in the history of science and technology, in particular, in the scientific, educational and organizational activities of prominent Ukrainian scholars who selflessly worked for the development of science and education in Ukraine. In recent years, studies 
have been published covering the development of science and education, including technical, through the study and reflection of the scientific, educational and social activities of a prominent individual. One of these personalities was Petro Vasylyenko - Academician of the National Academy of Agrarian Sciences, Corresponding Member National Academy of Sciences of Ukraine, Academician of the Russian Academy of Agricultural Sciences, Doctor of Technical Sciences, Professor. In the fields of agricultural mechanics, agricultural engineering, mechanization, electrification and automation of agricultural production in Ukraine, he had the achievement of a world-class level that glorified domestic science far beyond the borders of the country. He was rightly called the leader of the agricultural mechanics of Ukraine.

Keywords: P.M. Vasylenko, coryphaeus, scientific treasure, scientists, agricultural (agricultural) mechanics, mechanization, automation, agriculture.

\section{НАУЧНОЕ НАСЛЕДИЕ АКАДЕМИКА П.М. ВАСИЛЕНКО (1900-1999)}

Для украинского общества, которое сейчас находится на стадии обновления, характерной чертой является растущая заинтересованность к истории науки и техники, в частности, и к научной, образовательной $u$ организационной деятельности выдающихся отечественных ученых, которые самоотверженно работали для развития науки и образования в Украине. 3 а последние годы появились исследования, которые освещают развитие науки и образования, в том числе технической, через изучение и осмысление научной, образовательной и общественной деятельности выдающейся личности. Одной из таких личностей был Петр Мефодиевич Василенко - академик Начиональной академии аграрных наук Украины, член-корреспондент Национальной академии наук Украины, академик Российской академии сельскохозяйственных наук, доктор технических наук, профессор. В области земледельческой механики, сельскохозяйственного машиностроения, механизации, электрификации и автоматизации сельскохозяйственного производства Украины он имел достижения мирового уровня, которые прославили отечественную науку далеко за пределами страны. Его по праву называли корифеем земледельческой механики Украины.

Ключевые слова: П.М. Василенко, корифей, научное сокровище, ученый, земледельческая (сельскохозяйственная) механика, механизация, автоматизачия, сельское хозяйство.

Висвітлення наукового скарбу корифея землеробської механіки України академіка П.М. Василенка $є$ складним і актуальним питанням i потребує сучасного погляду науковця й історика на цю проблему, оскільки це необхідно при оцінці сучасного стану і прогнозуванні розвитку землеробської механіки в 
майбутньому.

Аналіз останніх досліджень і публікацій [1, 2], в яких започатковано розв’язання даної проблеми, свідчить про те, що ще існують малодосліджені джерела, які стосуються наукового скарбу академіка П.М. Василенка.

Метою роботи $є$ комплексний аналіз наукового доробку академіка П.М. Василенка та визначення його внеску у розвиток вітчизняної технічної та аграрної науки.

Важливими шляхами розв’язання завдань даного дослідження є застосування принципів історизму, науковості, об'єктивності, комплексності джерел та методів: загальнонаукових та спеціальних історичних. Застосований інструментарій дав змогу обгрунтувати важливе значення наукових здобутків П.М. Василенка для подальшого розвитку землеробської механіки.

Аналіз наукового доробку академіка П.М. Василенка показав, що наукова спадщина вченого налічує понад 200 опублікованих наукових праць, які мають важливе значення для розвитку аграрної галузі народного господарства України.

Цінним внеском у землеробську механіку стала фундаментальна монографія академіка П.М. Василенка «Теория движения частицы по шероховатым поверхностям сельскохозяйственных машин», яка побачила світ у 60-х роках XX ст. У науково-технічній літературі до цього часу ще не існувало монографії, яка б настільки повно охоплювала кінематику руху матеріальних частинок по фрикційних поверхнях. Багато питань автор розробив вперше, а результати своїх оригінальних наукових досліджень він виклав в єдиній системі 3 узагальненням досліджень, виконаних іншими авторами [3].

Результати теоретичних розробок П.М. Василенка знайшли широке використання в процесі удосконалення об’єктів сільськогосподарської техніки. Так, вони були основою для розрахунку й проектування конструктивних i кінематичних елементів машин для сівби та внесення в грунт мінеральних i органічних добрив, для очищення й сортування вороху зернових культур тощо 
[4].

Фундаментальним внеском у землеробську механіку стала монографія академіка П.М. Василенка «Введение в земледельческую механику» [5], в якій викладено основоположні механіко-математичні передумови, необхідні для вирішення задач аналізу і синтезу параметрів механіко-технологічних процесів сільськогосподарського виробництва та процесів, що виконуються при вільному й невільному русі частинок і твердих тіл сільськогосподарських матеріалів під дією робочих органів машин й обладнання.

П.М. Василенко довів, що якщо будь-яку механічну систему віднести до нерухомих і рухомих систем декартових координат, а кінетичну енергію виразити в проекціях тільки на рухомі вісі декартових координат, то, здійснивши комплекс алгебраїчних перетворень проекцій швидкостей, можна отримати один загальний вираз кінетичної енергії й одну загальну систему диференційних рівнянь. У цьому випадку немає потреби складати диференційні рівняння для опису поведінки кожної окремо взятої механічної системи. Цей новий метод дозволяє описувати аналітично й моделювати функціонування будь-якої механічної системи, в тому числі сільськогосподарських машин i машинних агрегатів [5].

Ним запропоновано класифікацію динамічних систем стосовно сільськогосподарського виробництва, визначено вихідні та теоретичні передумови розробки цих проблем та накреслено напрями їх вирішення.

Академік П.М. Василенко одним із перших у світі почав широко використовувати механіко-математичні методи при проведенні досліджень у галузі сільськогосподарської техніки [2]. У моделюванні ним виділено й охарактеризовано такі методи: матеріально-технічний, абстрактно-логічний та комбінований. Вихідними передумовами моделювання П.М. Василенко вважав принцип ізоморфізму, метод аналогій, теорії розмірностей і подібностей. Для розв'язання задач синтезу оптимальних керуючих дій він запропонував широко застосовувати механіко-математичні методи у поєднанні 3 експериментальними. Ним розроблено методику синтезу оптимальних керувань 
роботою сільськогосподарських машин на основі принципу інваріантності. Він першим використав механіко-математичні принципи оптимізації як до проектування машини, так і в період випробування, оцінки й подальшого удосконалення. Учений широко застосовував такі методи оптимальних рішень як метод варіаційного числення, принцип максимуму і метод динамічного програмування.

П.М. Василенко наочно довів необхідність використання кібернетики у сільському господарстві на прикладі такої його галузі, як рільництво, що мало велике значення для прогресу цієї галузі.

Значним був внесок академіка П.М. Василенка у вивчення динаміки сучасних сільськогосподарських машин i машинних агрегатів [2]. Для дослідження складних (багатоланкових) динамічних систем П.М. Василенко рекомендує застосовувати метод Лагранжа (рівняння Лагранжа другого роду). При складанні диференціальних рівнянь динаміки систем 3 неголономними в'язями він пропонує використовувати методи Лагранжа у формі Раузса, Апеля, Ейлера, Якобі, Чаплигіна та інших. Для опису неконсервативних систем П.М. Василенко рекомендує використовувати канонічні рівняння Гамільтона. Ним запропонований метод, який дозволяє спростити складання диференціальних рівнянь для динамічних систем, які характеризуються наявністю у них відносних видів рухів. Виконані в цій області дослідження були спрямовані на створення методів оцінки динамічних характеристик самохідних типів сільськогосподарських машин та агрегатів. Одержані дані дають змогу прогнозувати поведінку машин як динамічних систем і на цій основі вирішувати питання щодо їх раціонального проектування. Особлива цінність його робіт у цій області полягає в тому, що вони грунтуються на використанні теорії лінійних і нелінійних диференційних рівнянь, теорії ймовірності та випадкових величин, методів варіаційного числення і т.п.

Значне місце серед робіт П.М. Василенка належить методиці визначення конструктивних i кінематичних параметрів робочих органів сільськогосподарських машин та теорії технологічних процесів [2]. На основі 
виконаних у цьому напрямку досліджень було розроблено теоретичні й експериментальні передумови щодо методики розрахунку ротаційних робочих органів культиваторів для міжрядного обробітку просапних культур, конструктивних параметрів дискових сошників сівалок і параметрів робочих органів бурякозбирального комбайна з обрізуванням гички на корені. Всі ці розробки були використані при створенні просапного ротаційного культиватора КФ-2,8, сівалок СД-24, «Ростсельмаш-24» та зерно-трав’яної універсальнокомбінованої СЗТУ-47, при створенні бурякозбирального комбайна 3 обрізуванням гички на корені.

Результати досліджень, які стосувались культиваторів увійшли у фундаментальну монографію «Культиваторы: (Конструкция, теория и расчёт)», написану П.М. Василенком у співавторстві 3 його учнем і послідовником П.Т. Бабієм [6].

Вагомим був внесок П.М. Василенка у вирішення проблем комплексної механізації сільськогосподарського виробництва. Для їх успішного розв'язання П.М. Василенком були розроблені такі технічні й теоретичні питання, як:

- теорія робочих процесів сільськогосподарського виробництва (обробіток грунту, сівба, збирання зернових і технічних культур, переробка кормів тощо);

- механіка сільськогосподарських машин (кінематика і динаміка, питання теорії коливань і сталості руху машин, теорія гідросистем для керування i регулювання машин, автоматичного регулювання і т. д.) [2].

Значним явищем в автоматизації процесів сільськогосподарського виробництва світу стала монографія П.М. Василенка та I.I. Василенка «Автоматизация процессов сельскохозяйственного производства», яка увійшла до Міжнародного фонду ООН. 3 їі допомогою Міжнародна економічна комісія ООН оцінювала стан автоматизації процесів сільськогосподарського виробництва в різних країнах світу.

Академіком П.М. Василенком проведена класифікація систем автоматичного регулювання, керування i контролю, розроблена методика побудови вихідних рівнянь та їх лінеаризація, визначені способи вивчення 
перехідних процесів, досліджені умови стійкості системи регулювання й проведена оцінка якості процесу автоматичного регулювання [7].

Елементи теорії кочення жорсткого колеса зі слідом, розробленої академіком П.М. Василенком, були використані американськими вченими при розробці місяцехода «LRV».

Наукові праці П.М. Василенка видані у Франції, Чехословаччині, Болгарії, Румунії, Китаї, цитуються в США [2]. Вагомим був внесок видатного ученого у великомасштабну працю 3 історії науки і техніки «Развитие механизации и электрификации сельского хазяйства Украинской ССР» (1988) [8].

Академіком П.М. Василенком започаткована наукова школа 3 землеробської механіки в Україні [9]. Вона має значні здобутки у вченні про обробіток грунту, механізації внесення добрив, сівби сільськогосподарських культур, хімічного захисту рослин від шкідників і хвороб, збиранні зернових та післязбиральному обробітку зерна, збиранні коренебульбоплодів, механізації садівництва і тваринництва та розробці технологій точного землеробства. Під його керівництвом захищено 7 докторських та близько 60 кандидатських дисертацій, дуже багато майбутніх докторів і кандидатів наук з ближнього i далекого зарубіжжя консультувались у вченого. Своїм безпосереднім учителем його вважають близько 200 науковців. Багато учнів академіка П.М. Василенка нині вже самі досягли вагомих наукових результатів - вони обрані академіками і членами-кореспондентами Національної академії аграрних наук України, Академії інженерних наук України, Російської академії сільськогосподарських наук та Міжнародної академії технічної освіти, очолюють провідні науководослідні інститути країни та факультети і кафедри, є провідними спеціалістами науково-дослідних лабораторій і конструкторських бюро, стали заслуженими працівниками народної освіти України, заслуженими винахідниками та заслуженими діячами науки і техніки України. Учні академіка П.М. Василенка - першопрохідці в Україні у розробленні технологій точного землеробства нового напрямку в розвитку землеробської механіки.

Наукова школа академіка П.М. Василенка дала путівку у життя школам 
його учнів - академіків НААН Л.В. Погорілого та В.М. Булгакова, членакореспондента НААН Д.Г. Войтюка, професорів О.О. Омельченка, М.С. Хоменка, В.С. Басіна та інших, що свідчить про ії довголіття і життєву силу.

Наукові здобутки П.М. Василенка знайшли своє визнання не тільки в Україні, а й у всьому світі. Видатного вченого було рекомендовано кандидатом на одержання Медалі Пошани 2-го тисячоліття. Його біографія увійшла до Галереї тисячоліття та сьомого видання Міжнародного довідника видатних людей минулого тисячоліття, виданого Американським Біографічним Інститутом (ABI) $[10,11]$.

Академіку П.М. Василенку, єдиному в Україні і одному з перших видатних вчених у галузі землеробської механіки на теренах колишнього Радянського Союзу, за видатні розробки проблем землеробської механіки, механізації і електрифікації сільського господарства була присуджена Золота медаль імені В.П. Горячкіна [12].

На відзначення видатних заслуг перед українською наукою ім'я академіка П.М. Василенка, розпорядженням Кабінету Міністрів України № 291-р від 12 травня 2004 р., було присвоєно Харківському національному технічному університету сільського господарства та дещо раніше, у 1999 р., рішенням Вченої ради Національного аграрного університету - кафедрі сільськогосподарських машин, на якій він працював з 1932 по 1999 рік.

Доведено, що академік П.М. Василенко, як видатний учений, залишив після себе неоціненний скарб, який налічує понад 200 наукових праць, переважна більшість 3 яких має світове визнання, і котрим ще тривалий час будуть користуватися вчені та інженери в галузі землеробської механіки, сільськогосподарського машинобудування, механізації й автоматизації сільського господарства.

Як талановитий педагог - виховав кілька поколінь учених та інженерів сільськогосподарського виробництва, що становлять інтелектуальну еліту інженерної служби сільськогосподарського виробництва України. Творчий 
шлях академіка П.М. Василенка гідний для наслідування теперішньому i прийдешнім поколінням.

\section{Список використаних джерел та літератури}

1. Войтюк Д. Г., Деркач О. П. Внесок академіка П. М. Василенка у розвиток теоретичних основ землеробської механіки. Науковий вісник Луганського начіонального аграрного університету. Серія: технічні науки. Луганськ : вид-во ЛНАУ. 2011. № 29. С. 6-12.

2. Деркач О. П. Діяльність академіка П. М. Василенка в контексті розвитку землеробської механіки в Україні : автореф. дис. ... канд. іст. наук : 07.00.07 / ДНСГБ УААН. Київ, 2006. 22 с.

3. Василенко П. М. Теория движения частицы по шероховатым поверхностям сельскохозяйственных машин. Киев : изд-во УАСГН. 1960. 283 с.

4. Василенко П. М. О совершенствовании сельскохозяйственной техники. Вестник сельскохозяйственной науки. 1970. № 4. С. 111-112.

5. Василенко П. М. Введение в земледельческую механику. Киев : Сільгоспосвіта, 1996. 252 с.

6. Василенко П. М., Бабий П. Т. Культиваторы : (конструкция, теория и расчет). Киев : изд-во УАСГН, 1961. 239 с.

7. Василенко П. М., Василенко И. И. Автоматизация процессов сельскохозяйственного производства. Москва : Колос, 1972.574 с.

8. Развитие механизации и электрификации сельского хазяйства Украинской ССР / Н. П. Барабан и др. Киев : Наукова думка, 1988. 472 с.

9. Войтюк Д. Г., Вергунов В. А., Мудрук О. С., Деркач О. П. Наукова школа академіка Василенка Петра Мефодійовича : монографія. Київ : Аграрна освіта, 2005. 72 с.

10. Лист від American Biographical Institute (ABI), February 13, 1998. Музей історії факультету механізації сільського господарства Національного університету біоресурсів і природокористування України. Особистий архів академіка П. М. Василенка. Папка № 50. Арк. 87.

11. Лист від American Biographical Institute (ABI), August 7, 1998. Музей історії факультету механізачії сільського господарства Національного університету біоресурсів і природокористування України. Особистий архів академіка П. М. Василенка. Папка № 50. Арк. 88.

12. Постановление Президиума ВАСХНИЛ от 7 декабря 1977 г. Архів Національного університету біоресурсів $і$ природокористування України. Оп. особ. справ викл. Спр. 15. Арк. 85.

\section{References}

1. Voytyuk, D. G. and Derkach, O. P. (2011). Vnesok akademika P.M. Vasylenka u rozvytok teoretychnykh osnov zemlerobskoi mekhaniky. [Contribution of academician M. Vasylenko to the development of theoretical fundamentals of agricultural mechanics]. Naukovyi visnyk Luhanskoho natsionalnoho 
ahrarnoho universytetu. Seriia: tekhnichni nauky [Scientific Bulletin of Lugansk national agrarian University. Series : technical Sciences]. Lugansk : publishing house of lnau 29, 6-12. [in Ukrainian].

2. Derkach, O. P. (2006). Diialnist akademika P. M. Vasylenka v konteksti rozvytku zemlerobskoi mekhaniky $v$ Ukraini : avtoref. dys. ... kand. ist. nauk: 07.00.07 [Activity of academician P. M. Vasylenko in the context of agricultural mechanics development in Ukraine. Abstract. dis. kand. ist. Sciences. 07.00.07] / DNSGB UAAN. Kiev. 22. [in Ukrainian].

3. Vasylenko, P. M. (1960). Teorija dvizhenija chasticy po sherohovatym poverhnostjam sel'skohozjajstvennyh mashin [Theory of the motion of particles on rough surfaces agricultural machines]. Kyiv: Publishing house WASHN. 283. [in Russian].

4. Vasylenko, P. M. (1970). O sovershenstvovanii sel'skohozjajstvennoj tehniki. [On the improvement of the farm machinery]. Vestnik sel'skohozjajstvennoj nauki [Journal of farm Sciences]. 4. 111-112. [in Ukrainian].

5. Vasylenko, P. M. (1996). Vvedenie $v$ zemledel'cheskuju mehaniku [Introduction to agricultural mechanics]. Kyiv : Slepot, 252. [in Russian].

6. Vasylenko, P. M. and Babiy, P. T. (1961). Kul'tivatory : (konstrukcija, teorija $i$ raschet). Cultivators: (design, theory and calculation). Kyiv: Publishing house WASHN, 239. [in Russian].

7. Vasylenko, P. M. and Vasylenko, I. S. (1972). Avtomatizacija processov sel'skohozjajstvennogo proizvodstva. Automation of agricultural production processes. Moscow : Ear. 574. [in Russian].

8. Baraban, N. P., et al. (1988). Razvitie mehanizacii i jelektrifikacii sel'skogo hazjajstva Ukrainskoj SSR [Development of mechanization and electrification of agriculture of the Ukrainian SSR]. Kyiv : Scientific thought, 472. [in Russian].

9. Voytyuk, D. G., Vergunov, V. A., Mudruc A. S. and Derkach A. P. (2005). Naukova shkola akademika Vasilenka Petra Mefodijovicha: monografija [Scientific school of academician Vasylenko P. M. : monograph]. Kyiv : Agricultural education, 72. [in Ukrainian].

10. (1998). Lyst vid American Biographical Institute (AVI), February 13, 1998 [A letter from the American Biographical Institute (AVI), February 13, 1998]. Muzei istorii fakultetu mekhanizatsii silskoho hospodarstva Natsionalnoho universytetu bioresursiv $i$ pryrodokorystuvannia Ukrainy. Osobystyi arkhiv akademika P. M. Vasylenka [Museum of History of the Faculty of Mechanization of Agriculture of the National University of Bioresources and Natural Resources of Ukraine. The personal archive of academician P. M. Vasilenko]. Folder 50, ark. 87. [in Ukrainian].

11. (1998). Lyst vid American Biographical Institute (AVI), August 7, 1998 [A letter from the American Biographical Institute (AVI), August 7, 1998]. Muzei istorii fakultetu mekhanizatsii silskoho hospodarstva Natsionalnoho universytetu bioresursiv $i$ pryrodokorystuvannia Ukrainy. Osobystyi arkhiv akademika P. M. Vasylenka. [Museum of History of the Faculty of Mechanization of Agriculture of the National University of Bioresources and Natural Resources of Ukraine. The personal archive of academician P. M. Vasilenko]. Folder. 50, ark. 88. [in Ukrainian].

12. (1977). Postanovlenie Prezidiuma VASHNIL ot 7 dekabrja $1977 \mathrm{~g}$. [Decree 
of the Presidium VASKHNIL dated December 7, 1977]. Arkhiv Natsionalnoho universytetu bioresursiv $i$ pryrodokorystuvannia Ukrainy Archive of the National University of Bioresources and Natural Resources of Ukraine. Op. persons. affairs off., spr. 15, ark. 85. [in Russian].

\section{Рецензент:}

Бородай I.C., д.i.H., проф.

Надійшла до редакції 10.09.2018 р. 